\title{
Service Learning And Business Education: Distinctions Between Undergraduate And Graduate Business Students
}

\author{
Cleamon Moorer, Jr., Trinity Christian College, USA
}

\begin{abstract}
Research on service learning in business education often enumerates its efficacy and overall value. The focus on business students' attitudes toward service learning offers insight into program design and implementation of service learning into business curricula. This study investigates the distinctions between undergraduate and graduate business students' attitudes related to service learning in the business college of a Midwestern liberal arts university. A survey was distributed to a total of 210 students in three of the college's undergraduate and graduate business courses respectively. Students assessed their motivation, preparation, and skills to meet and fulfill service learning projects. Results of this study reflected that graduate business students possessed greater levels of commitment and skill sets to perform service learning projects. These data support an ideology that undergraduate business students may need more social development and academic preparation to gain the maximum benefit from service- learning projects. Traditional-age undergraduate business students were surveyed; thus responses to survey questions could have differed greatly if the undergraduate business students surveyed were nontraditional-aged or returning adult students.
\end{abstract}

Keywords: Business education, service-learning, undergraduate business students, graduate business students

\section{INTRODUCTION}

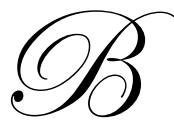

usiness students need real-world learning experiences to make socially-ethical individual contributions to today's ever-evolving global marketplace. "Management education, for good or ill, influences management practice by encoding key moral and behavioral tenets into undergraduate and MBA curriculum" (Godfrey, 1999, p. 364). In addition to moral and ethical development, current employers are looking for holistic conceptual knowledge and complimentary skills combined with basic business curricula. Karakaya and Karakaya (1996) reported that employers expect research, interpersonal skills, basic skills, and quantitative skills as the underlying basis of a business education.

Service learning can compliment business education and serve as a means to enable students to develop skills and gain real-world experience. As defined by Jacoby (1996), service learning is a "form of experiential education in which students engage in activities that address human and community needs with structured opportunities that are intentionally designed to promote student learning and development" (p. 7). Student learning and development is central to any and all academic curriculum. "The desired outcomes from real-world learning include skills development, knowledge enhancement, values clarification, and the improvement of application and integration abilities" (Billmoria, 1998, p. 266). Service-learning projects can be used to enable students to develop and exercise skills, make decisions, and put into practice some of their in-class learning. In-class integration activities, such as group discussions and case study analyses that are often utilized to create conceptual and holistic understanding, can be enhanced by teaching and learning outside of the classroom.

Those of us who use service-learning as a teaching tool in our courses see it as just that---a tool that makes our classes a whole. Without the exposure to different contexts, people, issues, lifestyles, culture, needs, 
and the social and psychological demands of these projects, our classes would be less than optimal. The knowledge we are helping to create for our students, our communities, and ourselves using service-learning is both generative and multidimensional, containing aspects of reality that no textbook can provide. (Kenworthy-U'Ren \& Peterson, 2005, p. 274).

In light of all of the proponents of service learning and its valuable integration into business curricula, there does exist research that prescribes caution in the pursuit of service-learning projects. The focus of research has to shift to students and students' ability to grasp the concepts, purpose, and the end goals of assigned service-learning projects. Business faculty members are responsible for assessing where students are in their apprehension of course content and their ability to make a substantive contribution to a service-learning project.

The underside of service learning is not just about students' inability to get it (which is rarely from unwillingness or recalcitrance, instead having to do with cognitive, capacity, self-knowledge, and interpersonal maturity) or to process new experience, but also about our inability to anticipate comments, understand where students are in their development process, and acknowledge complex issues." (Jones, 2002, p. 14-15)

There is presumably a difference in undergraduate and graduate students' development, self-knowledge, and skill sets. There are numerous studies that discuss distinctions between undergraduate and graduate business students as related to ethical development and cognitive development. A study conducted by Borkowski and Ugras (1992), revealed several distinctions between undergraduate and graduate business students in terms of ethical development..."undergraduate students were found to be more justice oriented than their MBA counterparts, who were more utilitarian in their ethical approach" (p. 369). Researchers have also focused on age of students, "....ethical positions seem to change with age, but no single factor can be identified as causing this change" (Borkowski \& Ugras, 2002, p. 973). In terms of cognitive development, traditional-aged undergraduate and young MBAs are often categorized similarly. Greater levels of exposure to new ideas and environments have an impact on one's cognitive development.

Undergraduate and graduate business students are positively and/or negatively impacted by in-class and out-of-class learning experiences. It is presumable that graduate business students with full-time jobs have greater exposure to external learning and development than undergraduate business students. However the single factor of full-time employment does not directly impact an individual's rate of development and maturity, “...the learning impacts of students' out-of-class experiences are probably cumulative rather than catalytic" (Terenzini, Pascarella, \& Blemling, 1999, p. 620).

Taking all of the presumed differences between undergraduate and graduate business students into consideration does not assess or imply each group's attitudes or readiness to successfully learn from and participate in service-learning projects.

\section{Purpose of Study}

First, this study is intended to reexamine how service-learning projects can be used as a tool to better prepare undergraduate and graduate business students by reviewing literature related to service-learning and business education. Secondly, this study investigates undergraduate and graduate business students' self-perceived levels of (1) commitment; (2) confidence; (3) motivation; (4) business education preparation; (5) skills (interpersonal, technical, conceptual) as related to service learning. The distinctions between undergraduate and graduate business students self-perceived levels of each factor is also observed and evaluated.

\section{Research Questions}

The study explored the following research questions:

1. Are there differences between undergraduate and graduate business students' perceptions of self as related to service learning? 
2. What are some of the differences between undergraduate and graduate business students' perceptions of self as related to service learning?

\section{Limitations}

This study examines the self-perceptions of a traditional-aged group of undergraduate business students and a presumably more work-experienced group of graduate business students at a predominately-white mid-western university. Variables such as age, gender, and ethic background contribute some special qualities to learners (Anderson \&Adams, 1992; Baxter-Magdola, 1992; Parascella \& Terrenzini, 1991). Some undergraduate business classrooms are mixed with traditional-aged undergraduate students and returning adult learners well above the age of 22. The average age of MBA students in this study is 35; many graduate level business classrooms are filled with students from age 24 to 45 and beyond. Thus, the distinctions presented in this study are more representative of traditional liberal arts college or master's university undergraduate and graduate student bodies.

\section{REVIEW OF LITERATURE}

Today's undergraduates urgently need to see the relationship between what they learn and how they live. "Specifically, we recommend that every student complete a service project---involving volunteer work in the community or at the college..."(Boyer, 1987, p. 218). A similar recommendation is made for students in MBA programs insofar as these students have not already had "this kind of exposure to breadth in their baccalaureate degree programs" (Porter \& McKibbin, 1988, p. 317).

These recommendations are not always easy to adhere to in business education. Implementing service learning into business education does not come without great challenge. "Combining community service and academic courses and successfully accomplishing service goals while achieving learning outcomes is challenging, particularly in undergraduate business courses whose curriculum content is frequently technical and standardized" (Andrews, 2007, p. 19). However, there has to be a visible link between the technical disciplines and society. Service learning can be used to establish that visible link.

Service-learning pedagogies help students create behavioral intentions to continue to serve their communities. Much of our academic course work in ethics, stakeholder analysis and management, organizational behavior, and corporate social responsibility work to change students' cognitive approaches to dealing with problems. Cognitive training many have powerful effects on the attitudes of students toward their moral roles as managers (Godfrey, 1999, p. 374).

“Service-learning pedagogies seek to enhance students' technical skills by giving them a concrete, experiential base for skill application" (Godfrey, 1999, p. 369). Today, business education aims to build more than technical skills. "For students, service learning develops leadership skills and encourages understanding of civic responsibilities, contemporary social issues, and diversity in the workplace" (Gujarathi \& McQuade, 2002, p. 146). Numerous diverse sources have conclusively cited service learning as an integral component of business education.

\section{Business Education}

On the whole business schools have been slow in embracing and implementing service-learning activities in curricula. (Gujurathi \& McQuade, 2002). However, service learning projects do not necessarily need to reside in a specialized 'service learning' course within a business curriculum exclusively. Eyler, Giles, Grey and Stenson (2001), provided a comprehensive review of service learning research focused on university faculty, staff and students referencing 135 published and unpublished studies between 1993 and 2000. Andrews (2007) offered a summation of Service Learning (SL) applications exclusive to business education spanning from 1996 to 2007. Andrews' (2007) study depicted multiple service learning projects at reputable business schools that involved all tenets of business courses from accounting, finance, business ethics, human resource management, management marketing, and even statistics. Several researchers have conveyed that it is the responsibility of business education to enable students to make things better in the communities in which they serve and reside regardless of specific business discipline. 
We have argued that (1) management education is a "public good", not a private good practiced solely for personal benefit; (2) universities in general and business/management schools in particular - should use service learning as a pedagogy to link management skills and competencies to make things better in the community and (3) the educational value of service-learning enables students, faculty, and community to shape an exchange of ideas and experience that can result in "win-win-win" outcomes for students, universities, and communities. (Waddock \& Post, 2000, p. 52)

Service learning in business education has proven to be beneficial to undergraduate and graduate business students in number of different ways. "Service learning projects can effectively engage students in the uncertainties, difficulties, and complexities of present-day management and better them for graduate schools and future careers" (Govekar \& Rishi, 2007, p. 4). Service-learning projects can be used as a means to change or develop students' mindsets regarding civic responsibility and civic engagement. "Civic engagement means believing that you can and should make a difference in enhancing your community, and it means possessing the combination of knowledge, skills, and values necessary to help make that difference" (Ehrlich, 1997, p. 57).

\section{Business Students' Self-Perceptions}

Earlier studies have shown that efficacy beliefs contribute significantly to an individual's level of motivation and performance. Motivation and self-efficacy are important factors when determining a student's competency to take on civic responsibilities. Thus, the higher the perceived self-efficacy, the greater the level of motivation to accomplish tasks (Bandura \& Locke, 2003). Out-of-class learning activities and exercises give students and opportunity to test their skills in completing real-world tasks. Some students may have a preconceived higher or lower self-assessment of their actual capabilities. "Intervention is important when educators believe that students' perceptions of their abilities are inaccurate" (Tucker \& McCarthy, 2001, p. 242). A service-learning project can be a valuable intervention to help students get an accurate assessment of their skills. "The greater the perceived skill variety, task identity, task significance, and feedback embedded in their service-learning experience, the more likely were they to value it and see it as positively linked to their practical skills development" (Lester, Tomkovick, Wells, \& Flunker, 2005, p. 290).

\section{METHOD}

\section{Research Design and Rationale}

The study was based on an ex-ante assessment/evaluation. An ex-ante assessment/evaluation is defined as "assessing/evaluating quality before a programme or institution is launched..." (Campbell \& Rozsnyai, 2002, p. 132). This design was appropriate because it serves as an evaluation of a group of undergraduate business students and a group of graduate business students to assess the similarities and difference(s) between their attitudes prior to formal participation in any business school facilitated service-learning project. The study targeted a Midwestern liberal arts university that planned to enhance the business curriculum to include service-learning projects, internships, and co-op opportunities.

\section{Sample}

The researcher applied and received approval from the university's Institutional Review Board to disseminate a service-learning survey to approximately 200 business students. Upon approval, the researcher sent a mass e-mail to all of the college's business faculty members explaining (1) purpose of the research project and (2) to solicit participation in the dissemination of the survey. 12 of the college's faculty members agreed to facilitate it to their classes. In an attempt to randomly select groups of students, the researcher accepted the offer of participation from every other faculty member that responded. Ultimately, 3 undergraduate and 3 graduate courses were used to generate the study's sample.

\section{Participants}

In the fall of the 2007, approximately 40 students were enrolled in each of the three undergraduate business 
courses selected and 30 students were enrolled in each of the three graduate business courses selected. The sample consisted of 120 undergraduate and 90 graduate business students. This sample was appropriate quantitatively because it represents a decent proportion of the entire business student population; and qualitatively because it is the first academic year of the business school's plan to begin implementing service-learning projects into the business curricula.

\section{Procedure and Instrument}

A total of 189 completed surveys from undergraduate and graduate business students were analyzed and formed the basis of this analysis. Approximately 7 percent of surveyed students (13 of 189) reported participation in a service-learning activity. The survey was circulated to a cross-section of undergraduate and graduate student classes in accounting, business, government and society (BGS), finance, marketing, and operations. The survey consisted of three parts: a collection of demographics, a description of service-learning experience (if applicable), and a self-assessment. The front page of the survey allowed students to identify individual demographics such as age and gender; student also were able to denote their rank and GPA. Students were asked to answer whether they had ever participated in a service learning project and if so to briefly describe the event and its outcomes.

The second page of the self-assessment presented questions constructively designed to gather students' ideas and assessments of themselves as related to service learning. Questions were designed to describe attitudes and behaviors associated with business education and academic service learning such as: motivation, responsibility preparation, skills (conceptual, interpersonal, and technical), and academic preparedness as a business major. Students rated themselves using a Likert scale ranging from 5 (strongly agree) to 1 (strongly disagree). An earlier work presented by Toncar, Reid, and Anderson (2005), described the (SErvice LEarning Benefit) SELEB scale, which has been implemented at several universities to assess the impact of service learning projects on the dimensions of interpersonal skills, practical skills, citizenship, and personal responsibility.

\section{Reliability and Validity}

The reliability of a research instrument is determined by its stability, equivalence, internal consistency, and practicality. (Cooper \& Schindler, 2003). "Practicality has been defined as economy, convenience, and interpretability" (Thorndike, 1996, p.199). This study is practical because the survey instrument was not purchased from a secondary source; it was self-designed by the researcher. Secondly, the subjects were convenient to reach with the assistance of fellow business faculty members at the research site. Lastly, the results of the survey are easily interpretable due to the clear detailed instructions for administration on the first page of the survey. (Cooper \& Schindler, 2003).

Toncar, Reid, Burns, Anderson, and Nguyen (2006) thoroughly assessed and confirmed the validity of the SELEB scale..."we first assessed the unidimensionality of the scale items, then convergent and discriminate validities were investigated, and, finally, the scale items' reliabilities were evaluated" (p. 231). The survey used in this study adds the variables of motivation and business preparation and does not use quite as many scale factors as the SELEB either. This survey has face validity because it captures answers and responses to the questions that are posed. Secondly, this scale has preliminary convergent validity because it uses several of the same constructs presented in the SELEB scale. (Cooper \& Schindler, 2003).

The following questions/statements are included in the survey:

1. I have a strong commitment to meet a community need.

2. I would be successful in meeting a need of a community through a community service activity.

3. I can learn from an organized community service activity that reflects upon formal business education.

4. I have a civic responsibility as a business major to conduct service to the community.

5. I am committed to serving the community as a business major.

6. I have the technical skills needed to engage in a 'service learning' activity.

7. I have the conceptual skills needed to engage in a 'service learning' activity.

8. I have the interpersonal skills needed to engage in a 'service learning' activity. 
9. My "formal education in business" has prepared me to serve the community in an organized 'service learning' activity.

10. My "formal education in business" has included course work in 'service learning'.

\section{Data Analysis}

The mean raw scores of undergraduate and graduate responses to each survey question were measured and then observed for differences. To determine whether a difference of scores was statistically significant, a t test for relational means was administered assuming equal variances. Equal intervals were assumed for the ordinal data in conducting the $t$ test. The mean scores were also used to calculate a confidence interval for the analysis. The variance of the sample was also used to estimate the variance of the population. Critical values from the students' $t$ distributions were used when computing the confidence intervals. An alpha level of .05 was used for all of the statistical tests.

\section{Survey Response Rate and Demographic Information}

The over-all response rate was $90 \%$ of the 210 undergraduate and graduate business students in participating classes. $91 \%$ of the sample's respondents identified themselves as White/Caucasian, Asian, or other; 5\% Black/African American; 4\% Non-white/Hispanic or Latino. A total of 103 undergraduate and 86 graduate surveys were completed. Of the undergraduate survey respondents, $57 \%$ were male and $43 \%$ were female; the average age was 22; and the average GPA was 3.17.

Of the graduate survey respondents, $48 \%$ were male and $52 \%$ were female, the average age was 34 ; and the average GPA was 3.75 .

\section{FINDINGS} descriptions:

Students that have previously participated in formal service-learning projects provided the following

\section{Undergraduate business students}

- $\quad$ My fraternity is involved in a service day each year to help out people in the community.

- $\quad$ During spring break we took a service trip to Terre Haute, IN to volunteer at a homeless shelter.

- I organized a 'run for life' event with other activity committee members at my community's local park

- We've discussed personal growth and helping others in our freshmen seminar class.

\section{Graduate business students}

- $\quad$ My current employer collects gifts from employees for needy families each year.

- In undergrad, in a nutrition class each student had to volunteer at a food depository or soup kitchen during Thanksgiving Break.

- I was once involved in a dance company that taught dance and performed for less fortunate youth.

- I've cleaned up at homeless shelters and schools in the area.

- Taught vacation bible school and spent time at nursing homes with elderly people that had no or distant relatives.

- "Shoes for soles", I participated in a shoe drive to collect donated shoes and send them to countries where people did not have shoes...

- $\quad$ Participated in 'Project Green' helping to raise awareness about the environment...

- $\quad$ Visited a home for abused women and created a pamphlet to raise awareness and promote donations.

- I've facilitated workshops to educate seniors on identity theft and fraud.

Table 1 shows the comparison of the relational means of both groups in response to each survey question. In review of the data collected on the second page of the survey, the undergraduate and graduate students differed 
greatly in the areas of commitment; conceptual skills; interpersonal skills; and formal education in business. (See Table 1).

Table 1

A t-Test for relationship means of undergraduate and graduate student survey responses

\begin{tabular}{lccc}
\hline Variables & $\begin{array}{c}\text { u-graduate } \\
\text { M }\end{array}$ & $\begin{array}{c}\text { Graduate } \\
\text { M }\end{array}$ & P \\
\hline $\begin{array}{l}\text { Commitment } \\
\text { (in general) }\end{array}$ & 3.38 & 3.73 & .014 \\
Success & 3.77 & 4.01 & .051 \\
Learn & 4.01 & 4.16 & .189 \\
Civic responsibility & 3.59 & 3.54 & .743 \\
Commitment \\
(as a business major) & 3.42 & 3.63 & .141 \\
Technical skills & & & .385 \\
Conceptual skills & 4.01 & 4.11 & $* .010$ \\
Interpersonal skills & 3.99 & 4.25 & $* * .005$ \\
Formal education in business & 4.11 & 4.40 & $* .004$ \\
Coursework in SL & 3.77 & 4.09 & .066 \\
\hline
\end{tabular}

Note: $* \mathrm{p}<.05 . * * \mathrm{p}<.01$

In reply to the comment: "I have a strong commitment to meet a community need"; graduate business students expressed a greater sense of responsibility to meet a community need than undergraduate business students. With an alpha level of .05 , the variable of 'commitment' was statistically significant, $p<.02$. There was no statistical significant difference between the 2 groups in their responses to the statement "I am committed to serving the community as a business major", $\mathrm{p}>.05$. 'Conceptual skills' was also statistically significant, $\mathrm{p}=.01$. Graduate students assessed themselves higher than undergraduate students, $(M=4.25)$ and the overall mean for undergraduate students in relation to 'conceptual skills' was $(\mathrm{M}=3.99)$.

As indicated in Table 1, there are significant differences between undergraduate and graduate business students' assessments of the variables of 'interpersonal skills' and 'formal education in business', $\mathrm{p}<.01$, respectively.

Based on the data presented in Table 2, graduate business students assess themselves much differently than undergraduate business students in the areas of commitment, conceptual skills, interpersonal skills, and formal education in business. The mean values of graduate business student scores in the areas of commitment $(\mathrm{M}=3.73)$, conceptual skills $(\mathrm{M}=4.25)$, interpersonal skills $(\mathrm{M}=4.4)$, and formal education $(\mathrm{M}=4.09)$ fall above all of the 95\% confidence interval ranges for undergraduate business student data collected. 
Table 2

Comparison of means and interval ranges for both groups on key variables.

\begin{tabular}{|c|c|c|c|c|}
\hline Variable & $\mathbf{M}$ & SD & SE & $95 \% \mathrm{CI}$ \\
\hline & & $\begin{array}{l}\text { u-graduates } \\
\text { students }\end{array}$ & & \\
\hline $\begin{array}{l}\text { Commitment } \\
\text { (in general) }\end{array}$ & 3.38 & .87 & .08 & $3.1-3.5$ \\
\hline Conceptual Skills & 3.99 & .87 & .08 & $3.8-4.1$ \\
\hline Interpersonal Skills & 4.11 & .78 & .08 & $3.9-4.2$ \\
\hline Formal education in business & 3.77 & $\begin{array}{c}.77 \\
\text { Graduate students }\end{array}$ & .07 & $3.6-3.9$ \\
\hline $\begin{array}{l}\text { Commitment } \\
\text { (in general) }\end{array}$ & 3.73 & 1.03 & .11 & $3.5-3.9$ \\
\hline Conceptual Skills & 4.25 & .63 & .07 & $4.1-4.3$ \\
\hline Interpersonal Skills & 4.40 & .62 & .06 & $4.3-4.5$ \\
\hline Formal education in business & 4.09 & .73 & .07 & $3.9-4.2$ \\
\hline
\end{tabular}

\section{DISCUSSION}

Based on the findings of this research study, graduate business students have a higher level of commitment, greater interpersonal and conceptual skills, and more formal education in business as related to service learning than undergraduate business students. Undergraduate and graduate business students perceive themselves very similarly as related to success in participating in a service learning project; learning from a community service activity; civic engagement; and technical skills. As Jones (2002) forewarned when students do not 'get it' about service-learning projects it is usually not from their unwillingness, instead it has to do with their capacity and interpersonal maturity to process a new experience. Undergraduate business students should be adequately matched with projects that are in alignment with their skill-sets, eagerness or interest, and formal educational preparation. "Students will quickly get in over their heads if course design and expectation requires skill and competence in areas for which they are unprepared" (Jones, 2002, p. 14). Even though service-learning projects help to build students skill levels, many may become overwhelmed by the roles and tasks required of some service-learning projects. This research study provides insights for administrators and business faculty when and while developing service-learning projects.

\section{CONCLUSIONS AND IMPLICATIONS}

This study infers that undergraduate business students may need greater development of interpersonal and conceptual skills in order to fulfill the objectives of some service learning projects. It suggests that faculty and administrators should assess the preparation, commitment, skill sets and readiness of undergraduate business students when planning and formulating service learning projects. Service-learning projects can also be used as a means to help develop undergraduate business students' skill sets. Service learning projects can be implemented involving both undergraduate and graduate business students simultaneously. Graduate business students can serve as coaches, mentors, and partners in the development of undergraduate students and in the pursuit of meeting the objectives of the service-learning project.

Further research opportunities exist and can be conducted on the basis of the research found in this study. This survey can be administered in a pretest and posttest data analysis format to observe and evaluate changes in students' perceptions of themselves before and after participation in a formal service-learning project. The attributes 
of age and GPA could be evaluated in greater depth to find correlation between them and the other variables assessed. Data on the work experience factor of graduate students could also be collected and interpreted as a precedent to higher perceptions of conceptual skills. Lastly, studies such as this add to the clarification of the need for business education to serve and prepare students through the holistic development of business skills and soft skills in and outside of the classroom so that they can add greater value to business, industry, and to the global communities in which they will reside and work.

\section{AUTHOR INFORMATION}

Dr. Cleamon Moorer, Jr., is an assistant professor of business and Small Business Institute Director at Trinity Christian College. Dr. Moorer has seven years of teaching experience in higher education which includes an assistant professorial lectureship at Saint Xavier University and adjunct professor positions at Walden University and Roosevelt University. Prior to teaching, he served AT\&T for several years as an engineer, planner, and global service executive; after leaving AT\&T he founded Moorer Customer Care Solutions Consulting, a regional management consulting firm dedicated to assisting small and intermediate business managers and owners.

\section{REFERENCES}

1. Anderson, J.A. \& Adams, M. (1992). Acknowledging the learning styles of diverse student populations: Implications for instructional design. Teaching for Diversity, New Directions for Teaching and Learning, 49. San Francisco, CA: Jossey-Bass.

2. Andrews, C.P. (2007). Service learning: Applications and research in business. Journal of Education for Business, 83(1), p.19.

3. Bandura, A. \& Locke, E.A. (2003). Negative self-efficacy and goal effects revisited. Journal of Applied Psychology, 88(1), 87-99.

4. Baxter-Magdola, M.B. (1992). Knowing and reasoning in college: Gender-related patterns in students' intellectual development. San Francisco, CA: Jossey-Bass.

5. Billmoria, D. (1998). From classroom learning to real-world learning: A diasporic shift in management education. Journal of Management Education, 22, 265-268.

6. Borkowksi, S.C., \& Ugras, Y.J. (1992). The ethical attitudes of students as a function of age, sex, and experience. Journal of Business Ethics, 11(12), 961-979.

7. Boyer, E.L. (1987). College: The undergraduate experience in America. New York, NY: Harper \& Row.

8. Campbell, C., \& Rozsnyai, C. (2002). Quality Assurance and the Development of Course Programmes. Paper presented at the Higher Education Regional University Network on Governance and Management of Higher Education in South East Europe Bucharest conference.

9. Cooper, D.R., \& Schindler, P.S. (2003). Business research methods ( $8^{\text {th }}$ ed.). New York: McGraw-Hill.

10. Ehrlich, T. (1997). Civic learning: Democracy and education revisited. The Educational Record, 78(3-4), 57.

11. Eyler, J., Giles, D.E., Gray, C.J. \& Stenson, C.M. (2001). At a glance: What we know about the effects of service-learning on college students, faculty, institutions and communities, 1993-2000: ${ }^{\text {rd }}$ Edition, Vanderbilt University.

12. Godfrey, P.C. (1999). Service learning: A call to action: Journal of Management Inquiry, 8(4), 363-378.

13. Govekar, M.A. \& Rishi, M. (2007). Service learning: Bringing real-world education into the b-school classrooom. Journal of Education for Business, 83(1), 4.

14. Gujarathi, M.R. \& McQuade, R.J. (2002). Service learning in business schools: A case study in an intermediate accounting course. Journal of Education for Business, 77, 144-150.

15. Jacoby, B. (Ed.). (1996). Service-learning in higher education. San Francisco, CA: Jossey-Bass.

16. Jones, S. R. (2002). The underside of service learning. About Campus, 7(4), 14-15.

17. Karakaya, F., \& Karakaya F. (1996). Employer expectations from business education. Journal of Marketing for Higher Education, 7(1), 9-16.

18. Kenworthy-U'Ren, A.L., \& Peterson, T.O. (2005). Service-learning and management education: Introducing the "we care" approach. Academy of Management Learning and Education, 4(3), 274. 
19. Lester, S.W., Tomkovick, C., Wells, T., Flunker, L., \& Kickul, J. (2005). Does service-learning add value? Examining the perspectives of multiple stakeholers. Academy of Management Learning \& Education, 4(3) 278-294.

20. Pascarella, E.T., \& Terenzini, P.T. (1991). How college affects students: Findings and insights from twenty years of research. San Francisco, CA: Jossey-Bass

21. Porter, L.W., \& McKibbin, L.E. (1988). Management education and development: Drift or thrust into the $21^{\text {st }}$ century? New York, NY: McGraw-Hill.

22. Terenzini, P.T., Pascarella, E.T., \& Blimling, G.S. (1999). Students' out-of-class experiences and their influence on learning and cognitive development. Journal of College Student Development, 40(5), 610-623.

23. Thorndike, R.M. (1996). Measurement and evaluation in psychology and education. (6 ${ }^{\text {th }}$ ed.). Upper Saddle River, NJ: Prentice-Hall.

24. Toncar, M F., Reid, J.S., \& Anderson, C. E. (2005). Exploratory study to measure the validity of the SELEB scale. Journal of the Academy of Business and Economics, 5(1).173-179.

25. Toncar, M.F., Reid, J.S., Burns, D.J., Anderson, C.E., \& Nguyen, H.P. (2006). Uniform assessment of the benefits of service learning: The development, evaluation, and implementation of the SELEB scale. Journal of Marketing Theory and Practice, 14(3), 223-238.

26. Tucker, M.L., \& McCarthy, A.M. (2001). Presentation self-efficacy: increasing communication skills through service-learning. Journal of Managerial Issues, 13(2), 227-244.

27. Waddock, S., \& Post, J. (2000). Transforming management education: The role of service learning: In P.C. Godfrey \& E.T. Grasso (Eds.) Working for the common good: Concepts and models for service-learning in management (pp. 43-54). Washington, D.C: American Association for Higher Education. 